\title{
PERAN RETORIKA DALAM BIDANG PENDIDIKAN
}

\author{
Saroni \\ e-mail: inorasironi@yahoo.co.id
}

\begin{abstract}
Abstrak
Retorika adalah ilmu yang mempelajari kegiatan bertutur baik secara lisan ataupun tulisan. Retorik selalu terlibat dalam kehidupan bertutur masyarakat. Selama tindak dan usaha dalam kegiatan bertutur dilakukan orang selama tindak dan usaha itu dimaksudkan mempengaruhi pihak lain dan selama maksud mempengaruhi selalu ada dalam setiap kegiatan bertutur, maka selama itu pula orang terlibat dengan masalah retorik. Dengan kata lain tidak ada orang yang terlepas sama sekali dari retorik, sepanjang dia masih menyediakan diri hidup bermasyarakat. Dikatakan demikian atau kegiatan bertutur menggunakan bahasa sebagai media tutur, pemanfaatan retorika dalam bidang pendidikan ini artinya pendidikan yang merupakan ujung tombak dalam pengembangan sumber daya manusia harus bisa berperan aktif dalam peningkatan kualitas dan juga kuantitas.

Ada berbagai bidang profesi yang memanfatkan retorik secara perencana yang di maksudkan pemanfaatan retorik secara perencana ini ialah penggunaan retorik yang direncanakan sebelumnya secara sadar yang diarahkan ke suatu tujuan yang jelas. Perencanaan serta penggunaan ini tentu saja mendapat pengolahan yang baik sebelumya. Adapun bidang pendidikan yang memafaatkan langsung secara terencana salah satunya ialah pendidikan. Pendidikan harus diawali dengan dua pengamatan dasar, pertama bahwa orangorang dengan pendidikan yang lebih tinggi berbeda dengan orang yang kurang berpendidikan. Pengamatan kedua adalah perubahan individu yang terjadi setelah mereka mendapatkan yang lebih tinggi.

Kesimpulan dalam penelitian ini adalah retorika sangat berpengaruh pada tujuan tuturan yang ingin dicapai sehingga perlu sekali adanya persiapan dan perlu ada perencanaan terlebih dahulu dalam melakukan kegiatan bertutur. Seorang guru yang membina peserta didik harus menggunakan retorika yang baik, tujauannya adalah untuk mencapai target pendidikan itu sendiri, bahkan lebih dari itu guru menggunakan retorik yang baik agar membuat peserta didiknya betah dan bersemangat mengikuti kegiatan belajar mengajar. Dominansi topik tutur ini diperkuat dengan tindak tutur, dimana tampak terlihat bagaiman seorang guru melakukan tindakan yang sekiranya memancing penerima tutur untuk tertarik bahkan bersemangat dalam mengikuti kegiatan bertutur ini. Dua aspek tersebut memang penutur lakukan agar apa yang ingin disampaikan bisa tercapai tentunya lewat pendidikan.
\end{abstract}

\section{Keywords : Retorika dan Pendidikan.}

\section{A. PENDAHULUAN}

Retorika adalah ilmu yang mempelajari kegiatan bertutur baik secara lisan ataupun tulisan. Retorik selalu terlibat dalam kehidupan bertutur masyarakat. Selama tindak dan usaha dalam kegiatan bertutur dilakukan orang selama tindak dan usaha itu di maksudkan mempengaruhi pihak lain dan selama maksud mempengaruhi selalu ada dalam setiap kegiatan bertutur, maka selama itu pula orang terlibat dengan masalah retorik. Dengan kata lain tidak ada orang yang terlepas sama sekali dari retorik, sepanjang dia masih menyediakan diri hidup bermasyarakat. 
Kegiatan bertutur menggunakan bahasa sebagai media tutur, pemanfaatan retorika dalam bidang pendidikan ini artinya pendidikan yang merupakan ujung tombak dalam pengembangan sumber daya manusia harus bisa berperan aktif dalam peningkatan kualitas dan juga kuantitas. Upaya pengembangan pendidikan harus sesuai dengan proses pengajaran yang tepat agar anak didik dapat menerima pelajaran dengan baik. Dalam kegiatan pembelajaran tidak terlepas dari berbagai variabel pokok yang saling berkaitan yaitu kurikulum, guru/pendidik, pembelajaran, peserta. Dimana semua komponen ini bertujuan untuk kepentingan peserta. Berdasarkan hal tersebut pendidik dituntut harus mampu menggunakan berbagai pendekatan pembelajaran agar peserta didik dapat melakukan kegiatan belajar dengan menyenangkan. Hal ini dilatar belakangi bahwa peserta didik bukan hanya sebagai obyek tetapi juga sebagai subyek dalam pembelajaran. Peserta didik harus disiapkan sejak awal untuk mampu bersosialisasi dengan lingkungannya sehingga berbagai jenis pendekatan pembelajaran yang dapat digunakan oeh pendidik.

\section{B. KERANGKA TEORI}

\section{Pengertian Retorika}

Retorika secara umum didefinisikan sebagai seni berbicara dan sebuah teknik bagaimana menggunakan bahasa baik tertulis maupun oral untuk menginformasikan, mempersuasi, dan memotivasi khalayak (Andersen, 2008). Menurut kennedy dalam Herrick (2012) ilmuan sejarah yang menguasai sejarah retorika, telah mendefinisikan retorika sebagai sebuah energi yang melekat dalam emosi dan pikiran, ditularkan melalui sistem tanda, termasuk bahasa kepada orang lain untuk mempengaruhi keputusan atau tindakan. Sedangkan menurut Yoos (2009) mendefinisikan retorika sebagai seni pembuatan makna. Retorika dalam arti luas tentang arti membentuk, merombak, dan menciptakan itu. Ini adalah tentang keterampilan yang diperlukan untuk membuat seni pesentasi dan makna baru yang berguna dalam mencapai tujuan yang berhubungan dengan manusia lain.

Definisi ini bermanfaat dalam memahami retorika dan hal ini menunjukan bahwa retorika bukan hanya bagian dari siapa kita sebagai manusia, tetapi juga menunjukan bahwa ketika kita mengekspresikan emosi dan pikiran orang lain dengan tujuan mempengaruhi (membujuk) mereka, kita terlibat retorika.

\section{Asumsi Dasar retorika}

Menurut Herrick (2012) retorika memiliki lima asumsi dasar diantaranya:
1) Retorika bersifat direncanakan
2) Retorika disesuaikan dengan khalayak
3) Terkait dengan motiv manusiawi
4) Bersifat responsif terhadap situasi
5) Bertujuan persuasi

\section{Fungsi Retorika}

Menurut Herrick (2012) terdapat enam fungsi retorika dalam sistem sosial kemasyarakatan antara lain:

1) Fungsi menguji ide atau pemikiran

2) Retorika membantu dalam proses advokasi public

3) Retorika mendistribusikan kekuasaan politik

4) Retorika mendorong pencarian faktafakta

5) Retorika membentuk pengetahuan baru

6) Retorika membangun komunitas.

\section{Pengertian Pendidikan}

Pendidikan adalah usaha untuk mendewasakan orang baik dengan cara formal maupun informal.Pendidikan merupakan sebuah kata yang sangat familiar kita dengarkan di dalam hidup sehari hari, sebab pendidikan merupakan kegiatan 
penting yang dilakukan oleh hampir semua orang dari lapisan masyarakat.

Pendidikan sebagai sesuatu yang penting memang tidak terlepas dari banyaknya pendapat dan asumsi tentang arti dan definisi pendidikan yang sebenarnya. Pada artikel kali ini saya bermaksud menuliskan pendapat para ahli mengenai pendidikan yang tentunya berbeda beda tergantung pada persepsi masing masing. Artikel ini tentunya akan membuka pikiran kita tentang bagaimana menyikapi pendidikan.

\section{Pengertian pendidikan menurut Kamus Besar Bahasa Indonesia (1991)}

Pendidikan diartikan sebagai proses pembelajaran bagi individu untuk mencapai pengetahuan dan pemahaman yang lebih tinggi mengenai obyek-obyek tertentu dan spesifik. Pengetahuan tersebut diperoleh secara formal yang berakibat individu mempunyai pola pikir dan perilaku sesuai dengan pendidikan yang telah diperolehnya.

Pengertian pendidikan Menurut UU No. 20 tahun 2003

Pendidikan adalah usaha sadar dan terencana untuk mewujudkan suasana belajar dan proses pembelajaran agar peserta didik secara aktif mengembangkan potensi dirinya untuk memiliki kekuatan spiritual keagamaaan, pengendalian diri, kepribadian, kecerdasan, akhlak mulia, serta ketrampilan yang diperlukan dirinya, masyarakat, bangsa, dan Negara.

\section{Pemanfaatan retorika secara umum}

Pemanfaatan retorika secara umum dapat dilihat dari pernyataan berikut. Menurut ahli retorik kenamaan "Donald C. Bryant". Menurutnya kehidupan bersama atau bermasyarakat ini penuh dengan masalah. masalah-masalah inilah yang membuat masyarakat itu dinamis dalam pertumbuhan dan perkembangannya. Tanpa masalah, masyarakat tersebut adalah masyarakat yang mati, dan bahkan mungkin tidak berhak disebut masyarakat lagi, karena memang tidak ada masyarakat yang masalah terhadap berbagai masalah yang ada atau timbul ataukah sengaja dimunculkan dalam kehidupan bermasyarakat itu, sebagian besar warganya memiliki pandangan, pendapat, penilaian, atau yang semacam dengan ini, karena perbedaan pribadi,pengetahuan, pengalaman antar warga masyarakat tersebut, maka pendapatnyapun berbedabeda terhadap persoalan yang sama itu perbedaan inilah yang antara lain membuat mereka bertutur, menuturkan pendapatnya dan pemecahannya, tentu saja dalam hubungan ini dia berusaha meyakinkan penanggap tuturnya bahwa apa yang dituturkannya itu adalah yang terbaik.

Untuk meyakinkan ini, secara sadar ataukah tidak dia memanfaatkan retorik yang tampak berupa pemilihan materi bahasa, jadi, pemanfaatan retorik secara umum yaitu ebagai alat pemecahan masalah, sehingga bisa dikatakan retorik selalu ada dalam kehidupanmanusia bermasyarakat.

\section{Pemanfaatan Retorika dalam bidang pendidikan}

Ada berbagai bidang profesi yang memanfatkan retorik secara perencana yang dimaksudkan pemanfaatan retorik secara perencana ini ialah penggunaan retorik yang direncanakan sebelumnya secara sadar yang di arahkan ke suatu tujuan yang jelas. Perencanaan serta penggunaan ini tentu saja mendapat pengolahan yang baik sebelumya. Adapun bidang pendidikan yang memafaatkan langsung secara terencana salah satunya ialah pendidikan. Pendidikan harus diawali dengan dua pengamatan dasar, pertama bahwa orang-orang dengan pendidikan yang lebih tinggi berbeda dengan orang yang kurang berpendidikan. Pengamatan kedua adalah perubahan individu yang terjadi setelah mereka mendapatkan yang lebih tinggi.

\section{C.METODE PENELITIAN}

Dalam penelitian ini, peneliti memunculkan latar belakang dan masalahmasalah yang actual. Dengan kata lain, masalah yang menjadi topic penelitian ini adalah masalah yang benar-benar sedang 
terjadi. Tidak dapat dipungkiri bahwa bahasa Sunda Lelea, Legok, dan Parean tidak ada perkembangan lebih lanjut malah hampir tidak dipakai lagi oleh penutur aslinya. Sehubungan dengan hal itu, maka peneliti menggunakan analisis kualitatif yang bersifat deskriptif

Deskriptif berarti menyarankan bahwa penelitian yang dilakukan semata-mata hanya berdasarkan fakta yang ada dan fenomena yang memang secara empiris hidup pada penutur-penuturnya, sehingga yang dihasilkan berupa perian bahasa yang bisa dikatakan sifatnya seperti potret paparan apa adanya. Perian deskriptif itu tidak mempertimbangkan benar salahnya penggunaan bahasa oleh penutur-penuturnya, hal iyu merupakan cirinya yang utama dan terutama (Sudaryanto, 1992:62).

\section{PEMBAHASAN}

\section{Retorika dalam bidang pendidikan}

Ada banyak pemanfaatan retorika dalam kehidupan sehari-hari, salah satunya dalam bidang pendidikan, sebelum membahas pemanfaatan retorika dalam bidang pendidikan,maka terlebih dahulu kita akan mengulas beberapa dasar dari pemanfaatan retorika. Keterlibatan orang dengan masalahmasalah retorik dalam kegiatan bertuturnya mengandung implikasi pengertian bahwa mereka terlibat dengan cara-cara memanfaatkan retorik. Persoalannya sekarang, bagaimanakah orang memanfaatkan retorik tersebut? Pada dasarnya ada tiga corak cara orang memanfaatkan retorika itu sendiri yakni ada 3 hal, maka untuk melugaskan serta menggambarkan pemanfaatan retorika, kami sajikan sebagai berikut.

Pemanfaatan retorika meliputi sebagai berikut, yaitu:

\section{Secara spontan atau intuisif}

Dalam kehidupan bertutur sehari-hari, pada umumnya orang memanfaatkan retorik itu secara spontan saja. Lebih-lebih lagi kalau topik tuturnya hanya merupakan topik pengisi waktu luang ataukah masalahmasalah lain yang diketengahkan dalam pergaulan akrab dan tidak resmi. Dalam situasi-situasi serupa ini, penutur tidak begitu banyak menghabiskan waktu dan tenaganya untuk memilih materi bahasa, memakai ulasan dan gaya tuturnya lebih banyak bersifat spontan saja, karena memang situasi tutur memungkinkan mereka bertindak demikian.

\section{Secara tradisional atau konvensional}

Berbicara tentang pemanfaatan retorik dalam kegiatan bertutur, ada masa-masa bahwa kebanyakan orang mengikuti konvensikonvensi bertutur seperti yang sudah digariskan oleh generasi yang terdahulu. Dengan kata lain, konvensi itu akhirnya menjadi tradisi yang ditaati turun-temurun. Misalnya para pujangga untuk menggambarkan seorang gadis cantik, digunakanlah ungkapan-ungkapan klise: "badannya langsing bagai pohon pinang; wajahnya bagai bulan purnama; matanya seperti bintang timur; hidungnya bak dasung tunggal; mulutnya laksana delima merekah dan seterusnya."

Pemanfaatan retorik secara tradisional, bukan hanya ada pada masa-masa lampau saja. Di tengah-tengah kehidupan modern sekarang ini pun masih berkembang kebiasaan-kebiasaan bertutur yang konvensional. Misalnya saja dalam rapatrapat atau pertemuan-pertemuan formil lainnya, sementara orang yang diberi kesempatan berbicara merasa perlu menyebut nama deretan pejabat yang hadir; mengucapkan terima kasih banyak-banyak atas kesempatan yang diberikan; dan lain sebagainya. Kebiasaan yang demikian ini agaknya sudah mentradisi dalam bertutur resmi pada akhir-akhir ini.

\section{Pemanfaatan retorik secara terencana}

Yang dimaksudkan pemanfaatan terencana dalam hal ini ialah penggunaan retorik yang direncanakan sebelumnya secara sadar diarahkan ke suatu tujuan yang jelas. 
Misalnya bidang politik, bidang usaha/ekonomi, karyawan bahasa, bidang kesenian dan bidang pendidikan.

Uraian di atas merupakan dasar dari pemanfaatan retorika, selanjutnya kita akan menelaah "pemanfaatan retorika dalam bidang pendidikan" yang merupakan salah satu pemanfaatan retorik secara terencana. Dalam bidang pendidikan sangat memerlukan retorika,dengan maksut dan tujuan mencapai keberhasilan dalam pembelajaran.

Pemanfaatan retorik secara terarah tampak menonjol pada proses balajar mengajar di kelas. Dalam proses ini para guru menerapkan prinsip pendidikan yang telah dipelajari sebelumnya dan memanfaatkan retorika berdasarkan jenis pembelajaran yang disajikan. Selain itu guru menggunakan alat peraga untuk menarik minat siswanya. Bermacam-macam usaha dilakukan untuk menarik minat siswanya, termasuk menggunakan tindak dan tuturan yang menyenangkan sekaligus produktif bagi perkembangan belajar peserta didiknya. Sehubungan dengan ini dapat kita pahami bahwa pendidkan merupakan proses penerapan retorik. "Keselurahan dari proses pengajaran didalam kelas adalah penerapan retorik" demikian kata Donald C. Bryant.jika seandainya dalam pendidikan tidak memanfaatkan retorika, maka pembelajaran akan tampak membosankan bagi peserta didiknya dan alhasil keberhasilan dalam pendidiknpun akan kurang terasa dan maksimal.

Ada beberapa hal yang perlu kita perhatikan dalam mengkaji sebuah retorika yang dipakai dalam berbagai aspek, termasuk juga pendidikan dan salah satunya adalah aspek ontologis. Analisis tersebut akan digunakan pada segmen selanjutnya, bagaimana aspek tersebut membangun sebuah retorika yang dipakai oleh seseorang sekaligus akan penulis sajikan data yang akan memperjelas kajian kita dalam bertutur. Begitu erat hubungan keduanya sehimgga retorika sangat mempengaruhi keberhasilan pendidikan. Lewat bertutur yang baik maka akan tercipta suatu kondisi dimana pendidikan sangat menyenangkan bagi peserta didik, namun sebaliknya penggunaan retorika yang kurang baik bahkan terkesan kaku akn menimbulkan kurang menarik minat dari peserta didik untuk selalu aktif mengikuti pembalajaran yang guru ajarkan. Dalam pendidikan upaya untuk mendewasakan peserta didik ditembuh dengan berbagai cara, salah satunya dengan tututran yang baik,menarik, produktif maka proses tersebut akan berjalan dengan lancar. Seorang guru kita ketahui perlu menggunakan retorika yang baik untuk menguasai kelas yang ia pimpin, maka dari itu dalam dunia kependidikan, sangat doperlukan tuturan yang memang diharapkan mencapai tujuan pendidikan.

\section{E. SIMPULAN}

Berdasarkan uraian tersebut dapat disimpulkan bahwa retorika sangat berpengaruh pada tujuan tuturan yang ingin dicapai sehingga perlu sekali adanya persiapan dan perlu ada perencanaan terlebih dahulu dalam melakukan kegiatan bertutur. Kita telah sama-sama membahas bagaimana dan seperti apa pemanfaatan retorika dalam bidang pendidikan. Seorang guru yang membina peserta didik harus menggunakan retorika yang baik, tujauannya adalah untuk mencapai target pendidikan itu sendiri, bahkan lebih dari itu guru menggunakan retorik yang baik agar membuat peserta didiknya betah dan bersemangat mengikuti kegiatan belajar mengajar.

Dominansi topik tutur ini diperkuat dengan tindak tutur, dimana tampak terlihat bagaiman seorang guru melakukan tindakan yang sekiranya memancing penerima tutur untuk tertarik bahkan bersemangat dalam mengikuti kegiatan bertutur ini. Dua aspek tersebut memang penutur lakukan agar apa yang ingin di samapikan bisa tercapai tentunya lewat pendidikan. Selanjutnya, dapat kita lihat ada sedikit kekurangan dalam kegiatan bertutur ini, yakni aspek Tuturan. Tuturan yang ideal sebaiknya memperhatikan komposisi yang baik, 
sehingga dalam menyampaikan tuturan semua yang akan dituturkan dapat dengan mudah dan lebih terasa efek psikologisnya. Kita sudah melihat, bahwa komposisi tuturannya tidak ideal dan kurang ideal. Hal ini dapat dilihat dari pengantar dan penutup yang terlalau sedikit sehingga kuranf adanya apersepsi dan penguatan dalam pembelajaran, hal yang guru lupakan adalah reword yang seharusnya ada di tahap pembukaan. Hal ini akan bertujuan untuk meningkatkan minat dan semangat pesrta didiknya. Penggalan isi sangat dominan dalam tuturan ini dan kurangnya pembuka serta penutup yang baik.

Menuturkan sesuatu bukanlah hal yang mudah, butuh pengalaman, penguasaan dan kemampuan bertutur yang biak dan benar sesuai konteksnya. Kegiatan bertutur sangat diperlukan dalam segala aspek kehidupan, begitupun pendidikan. Pendidikan harusnya mencapai tujuan yang sebenarnya dan dengan retorik yang baik dan benar, maka semua akan dapat terealisasikan dengan baik.

\section{Rekomendasi}

Dalam kegiatan bertutur dengan retorika yang baik, khususnya pada bidang pendidikan, sebaiknya :

1) Mempersiapkan tuturan dengan sistematik yang sesuai dengan peserta didik.

2) Memperhatikan medan tuturan.

3) Perlu adanya tuturan yang mampu membangkitkan gairah belajar.
4) Sampaikanlah tuturan itu dengan suka cita.

5) Media tutur yang baik juga sangat mempengaruhi keberhasilan tuturan.

6) Tarik simpatik peserta didik dengan retorika yang berkesan.

\section{DAFTAR PUSTAKA}

Andersen, Chistian. 2008. The Obama

Penomenon-A Comparative

Rhetorical. Analisys Copenhagen

Business School.

Gurah, I Gusti Oka. 1985. Retorik Sebuah

Tinjauan Pengantar . Bandung: Tarate.

Herrick James A. 2012. The History and

Theory of Retoric: An Introduction

Pearson College.

Keraf, Gorsyi. 2006. Diksi dan Gaya

Bahasa Seri Retorika. Jakarta: PT

Gramedia Pustaka Utama.

Sudaryanto. 1992. Aneka Konsep

Kedatangan Lingual dalam Linguistik.

Yogyakarta: Gajah Mada University

Press.

Suwito. 1985.Sosiolinguistik.

Surakarta: Fakultas Sastra Universitas

Sebelas Maret Pres. 